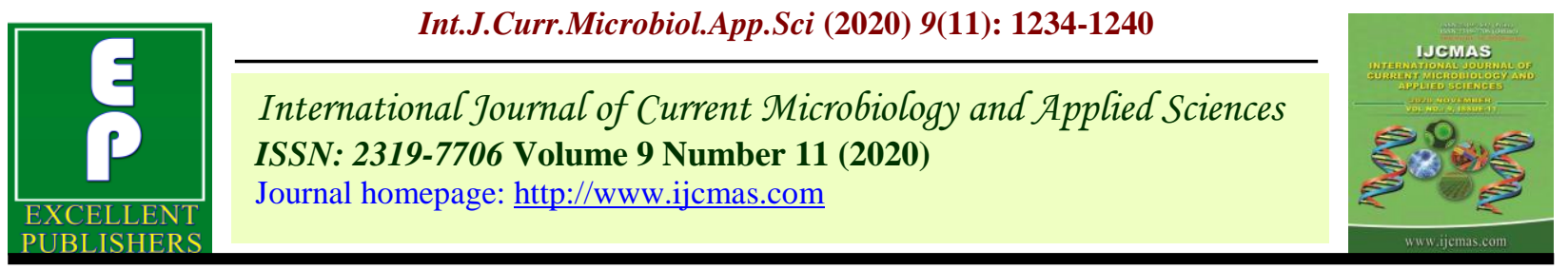

Original Research Article

https://doi.org/10.20546/ijcmas.2020.911.145

\title{
A Study on Effect of Foliar Application of Micronutrients on Growth, Fruit Set and Yield of Guava Cv. Allahabad Safeda
}

\author{
Saurabh Mani Maurya* and Deena Wilson \\ Department of Horticulture, Sam Higginbottom University of Agriculture, Technology and \\ Sciences, Prayagraj, India \\ *Corresponding author
}

A B S T R A C T

Keywords

Copper sulphate, Ferrous sulphate, Zinc Sulphate

Article Info

Accepted:

10 October 2020

Available Online:

10 November 2020
The present experiment was carried out during July 2019 to December 2019 in Central horticulture research farm of Department of Horticulture, SHUATS, Prayagraj. The experiment was conducted in Randomized Block Design with 15 treatment replicated thrice. The treatments were $\mathrm{T}_{1}$ (control), $\mathrm{T}_{2}$ (Copper sulphate @ $0.2 \%$ ), $\mathrm{T}_{3}$ (Copper sulphate@0.4\%), $\mathrm{T}_{4}$ ( Ferrous sulphate@0.2\%), $\mathrm{T}_{5}$ ( Ferrous sulphate @ $0.4 \%$ ), $\mathrm{T}_{6}$ (Zinc Sulphate @ 0.2\%), $\mathrm{T}_{7}$ (Zinc Sulphate @ 0.4\%), $\mathrm{T}_{8}\left(\mathrm{CuSO}_{4} @ 0.2 \%+\mathrm{FeSO}_{4} @ 0.2\right.$ $\%), \mathrm{T}_{9}\left(\mathrm{CuSO}_{4} @ 0.4 \%+\mathrm{FeSO}_{4} @ 0.4 \%\right), \mathrm{T}_{10}\left(\mathrm{CuSO}_{4} @ 0.2 \%+\mathrm{ZnSO}_{4} @ 0.2 \%\right), \mathrm{T}_{11}$ $\left(\mathrm{CuSO}_{4} @ 0.4 \%+\mathrm{ZnSO}_{4} @ 0.4 \%\right), \mathrm{T}_{12}\left(\mathrm{FeSO}_{4} @ 0.2 \%+\mathrm{ZnSO}_{4} @ 0.2 \%\right), \mathrm{T}_{13}\left(\mathrm{FeSO}_{4}\right.$ @ $\left.0.4 \%+\mathrm{ZnSO}_{4} @ 0.4 \%\right), \mathrm{T}_{14}\left(\mathrm{CuSO}_{4} @ 0.2 \%+\mathrm{FeSO}_{4} @ 0.2 \%+\mathrm{ZnSO}_{4} @ 0.2 \%\right)$, $\mathrm{T}_{15}\left(\mathrm{CuSO}_{4} @ 0.4 \%+\mathrm{FeSO}_{4} @ 0.4 \%+\mathrm{ZnSO}_{4} @ 0.4 \%\right)$. From the present investigation it is found that treatment $\mathrm{T}_{11}\left(\mathrm{CuSO}_{4} @ 0.4 \%+\mathrm{ZnSO}_{4} @ 0.4 \%\right)$ was found superior in terms of Plant height, Crown height, plant girth and $\mathrm{T}_{15}\left(\mathrm{CuSO}_{4} @ 0.4 \%+\mathrm{FeSO}_{4} @ 0.4 \%\right.$ $+\mathrm{ZnSO}_{4} @ 0.4 \%$ ) was found superior in terms of number of flowers, number of fruit set percentage, number of fruit, average fruit weight, fruit yield per plant, length of fruit, width of fruit and pulp thickness.

\section{Introduction}

Guava (Psidium guajava L.) is an important fruit crop of tropical and sub-tropical region of the world. It belongs to the family Myrtacae. It is classified under genus Psidium which contains 150 species, but only Psidium guajava has been exploited commercially. It is the fifth most important fruit in area after mango, citrus, banana, and apple and fifth most important fruit in production after banana, mango, citrus and papaya.
This fruit originated in tropical America and seems to have been growing from Mexico to Peru. The trees were domesticated more than 2000 years ago. It was spreaded rapidly through the worlds' tropics by Spanish and Portuguese soon after the discovery of the new world. Now it is cultivated in tropical and subtropical parts of several countries like India, Hawaii, Brazil, Mexico, Thailand, New Zealand, Philippines, Indonesia, China, Malaysia, Cuba, Sri Lanka, Venezuela, Australia, Burma, Myanmar, Israel, Pakistan and Bangladesh. India is the leading producer of guava in the world. 
In India it has been introduced in early 17th century and gradually become a commercial crop all over the country particularly in Maharashtra, Uttar Pradesh, Karnataka, Bihar, Orissa, Punjab, Uttrakhand, Gujarat, Madhya Pradesh and West Bengal. Guavas produced in Prayagraj region of Uttar Pradesh are best in the world.

Guava (Psidium guajava L.) is an important tropical and commercial fruit rich in dietary fibre, calcium, phosphorus and iron. In India, guava occupies an area of 2.64 lakh hectares with annual production of 40.53 lakh tonnes and productivity 15.3 MT/ha (Horticultural Statistics at a glance, 2018). In Uttar Pradesh, the area under guava crop is 49.53 thousand hectares with total production of 9.28 lakh tonnes and productivity $18.75 \mathrm{MT} / \mathrm{ha}$ (Horticultural Statistics at a glance, 2018).

Guava claims superiority over several other fruits because of its commercial and nutritional values. It is a rich and cheap source of vitamin $\mathrm{C}$ and pectin (a polysaccharide substance) (Agnihotri et al., 2002). It ranks third in vitamin $C$ content $(260$ $\mathrm{mg} / 100 \mathrm{~g}$ ) after barbados cherry and aonla. Guava contains 2 to 5 times more vitamin C than fresh orange juice. Besides it, is an excellent source of pectin $(0.5-1.8 \%)$ but has low energy (66 cal /100g).

The ripe fruits contain $12.3-26.3 \%$ dry matter, $77.9-86.9 \%$ moisture, $0.51-1.02 \%$ ash, 0.10$0.70 \%$ crude fat, $0.82-1.45 \%$ crude protein and $2.0-7.2 \%$ crude fiber. The fruit is also rich in minerals like phosphorus (22.5-40.0 $\mathrm{mg} / 100 \mathrm{~g}$ pulp), Calcium (10.0-30.0 mg/100g pulp) and Iron (0.60-1.39 mg/100g pulp) as well as vitamins like Niacin (0.20-2.32 $\mathrm{mg} / 100 \mathrm{~g}$ pulp), Panthotenic acid, Thiamine (0.03-0.07 mg/100 g pulp), Riboflavin (0.02$0.04 \mathrm{mg} / 100 \mathrm{~g}$ pulp) and vitamin-A (Mitra and Bose, 2001).
Guava has earned the popularity as "Poor man's apple" available in plenty to every person at very low price during the season. It is no inferior to apple for its nutritive value. It is pleasantly sweet and refreshingly acidic in flavour and emits sweet aroma. It is wholly edible along with the skin. Several delicious preserved products like Jam, Jelly, Cheese, Puree, Ice cream, canned fruit and Sherbat are prepared from ripe fruits of guava. Guava juice wine and guava pulp wine are also prepared from guava fruits.

Guava does equally well under tropical and sub-tropical climatic conditions. Under tropical climate due to availability of continuous heat and humidity, it produces fruits almost continuously. However in subtropical climate, there are three distinct periods of growth and fruiting. These three distinct periods are, Ambe bahar- February to March flowering and fruit ripens in JulyAugust, Mrig bahar- June to July flowering and fruit ripens October to December and Hasta bahar- October to November flowering and fruit ripens in February to April (Shukla et al., 2008).In north Indian guava flowers twice is year, first in April-May for rainy season crop and then in August- September for winter season crop. The yield of guava fruit is higher in Rainy season but quality of fruit is poor due to higher water content, less vitamin $\mathrm{C}$ and sugars, fruit are insipid and do not keep well. However, winter season yield is less than rainy season guava but quality is better than rainy season guava.

Foliar application of fertilizer is advantageous over soil application. It helps in uniform distribution of fertilizers, low application rates and quick response to applied nutrients (Kumar et al., 2015).Micronutrients like Fe, $\mathrm{Cu}$ and $\mathrm{Zn}$ are not only essential but also equally important like other macronutrients. These micronutrients help the plant uptake of major nutrients and play active roles in the 
plant metabolism like cell wall development, photosynthesis, chlorophyll formation, enzyme activity, nitrogen fixation and oxidation-reduction reaction. Guava responds significantly to applied micronutrients, especially zinc $(\mathrm{Zn})$, boron (B), copper $(\mathrm{Cu})$ and Iron $(\mathrm{Fe})$ for improving growth, yield and quality. Micronutrient especially Copper, Iron and Zinc are responsible for metabolic activities in fruit physiology. Application of micronutrients should be at first growth phase and before flowering.

Copper is one of the micronutrients needed in very small quantities by plants. Copper activates some enzymes in plants which are involved in lignin synthesis and it is essential in several enzyme systems. It is also required in the process of photosynthesis and assist in plant metabolism of carbohydrates and proteins.

Iron increases the chlorophyll content of leaves, reflecting the colour of leaves. Iron plays critical role in metabolic process such as DNA synthesis, respiration and photosynthesis.

Zinc takes part in chlorophyll synthesis, involved in biosynthesis of plant growth hormone and plays positive role in photosynthesis and nitrogen metabolism. Zinc is essential for auxin and protein synthesis, seed production and proper maturity. It also increase the fruit size as well as yield.

\section{Materials and Methods}

The Experiment was conducted in Randomized Block Design (RBD) with one control and 14 treatments at the central research farm of Department of Horticulture, Sam Higginbottom University of Agriculture, Technology and Sciences Prayagraj during 2019-2020. Total number of treatments were $14+1$ viz. $\mathrm{T}_{1}$ (control), $\mathrm{T}_{2}$ (Copper sulphate @
$0.2 \%), \mathrm{T}_{3}$ (Copper sulphate @ 0.4\%), $\mathrm{T}_{4}$ (Ferrous sulphate @ $0.2 \%$ ), $\mathrm{T}_{5}$ (Ferrous sulphate@ $0.4 \%$ ), $\mathrm{T}_{6}$ (Zinc Sulphate @ 0.2 $\%), \mathrm{T}_{7}$ (Zinc Sulphate @ 0.4\%), $\mathrm{T}_{8}\left(\mathrm{CuSO}_{4} @\right.$ $\left.0.2 \%+\mathrm{FeSO}_{4} @ 0.2 \%\right), \mathrm{T}_{9}\left(\mathrm{CuSO}_{4} @ 0.4 \%\right.$ + $\left.\mathrm{FeSO}_{4} @ 0.4 \%\right), \mathrm{T}_{10}\left(\mathrm{CuSO}_{4} @ 0.2 \%+\right.$ $\left.\mathrm{ZnSO}_{4} @ 0.2 \%\right), \mathrm{T}_{11}\left(\mathrm{CuSO}_{4} @ 0.4 \%+\right.$ $\left.\mathrm{ZnSO}_{4} @ 0.4 \%\right), \mathrm{T}_{12}\left(\mathrm{FeSO}_{4} @ 0.2 \%+\right.$ $\left.\mathrm{ZnSO}_{4} @ 0.2 \%\right), \mathrm{T}_{13}\left(\mathrm{FeSO}_{4} @ 0.4 \%+\right.$ $\left.\mathrm{ZnSO}_{4} @ 0.4 \%\right), \mathrm{T}_{14}\left(\mathrm{CuSO}_{4} @ 0.2 \%+\right.$ $\left.\mathrm{FeSO}_{4} @ 0.2 \%+\mathrm{ZnSO}_{4} @ 0.2 \%\right), \mathrm{T}_{15}$ $\left(\mathrm{CuSO}_{4} @ 0.4 \%+\mathrm{FeSO}_{4} @ 0.4 \%+\mathrm{ZnSO}_{4}\right.$ @ $0.4 \%$ ).

\section{Climatic condition in the experimental site}

The area of Prayagraj district comes under subtropical belt in the south east of Utter Pradesh, which experience extremely hot summer and fairly cold winter. The maximum temperature of the location reaches up to $46^{\circ}$ $\mathrm{C}-48^{\circ} \mathrm{C}$ and seldom falls as low as $4^{\circ} \mathrm{C}-5^{\circ} \mathrm{C}$. The relative humidity ranges between 20 to $94 \%$. The average rainfall in this area is around $1013.4 \mathrm{~mm}$ annually. However, occasional precipitation is also not uncommon during winter months.

\section{Results and Discussion}

The efforts have been made in this chapter to compare and interpret the result of various experiment carried out during the course of investigation with the findings of the other research works. The data recorded on various characters during "Mrig bahar" 2019-20, the course of investigation have been presented in this chapter along with table (Table 1). The present investigation entitled "A study on effect of foliar application of micronutrients on growth, fruit set, yield and quality of Guava Cv. Allahabad Safeda". The experiment was conducted in Randomized Block Design with 1 control +14 treatments, and three replications. 
The results of the experiment are summarized below.

In terms of plant height, the maximum plant height was recorded in $\mathrm{T}_{11}\left(\mathrm{CuSO}_{4} @ 0.4 \%+\right.$ $\left.\mathrm{ZnSO}_{4} @ 0.4 \%\right)$ with (183.06 cm) followed by $\mathrm{T}_{10}\left(\mathrm{CuSO}_{4} @ 0.2 \%+\mathrm{ZnSO}_{4} @ 0.2 \%\right)$ with $(170 \mathrm{~cm})$ and the minimum was recorded in $\mathrm{T}_{1}$ (control) with $(130.96 \mathrm{~cm})$. This study is supported by the findings of Saha et al., (2019), Singh et al., (2018), Guvvali et al., (2017) and Yadav et al., (2017) who reported that application of $\mathrm{CuSO}_{4}$ and $\mathrm{ZnSO}_{4}$ shows the maximum vegetative growth of the plant viz. plant height.

In terms of crown height, the maximum crown height was recorded in $\mathrm{T}_{11}\left(\mathrm{CuSO}_{4} @\right.$ $\left.0.4 \%+\mathrm{ZnSO}_{4} @ 0.4 \%\right)$ with $(117.20 \mathrm{~cm})$ followed by $\mathrm{T}_{10}\left(\mathrm{CuSO}_{4} @ 0.2 \%+\mathrm{ZnSO}_{4} @\right.$ $0.2 \%)$ with $(107.76 \mathrm{~cm})$ and the minimum was recorded in $\mathrm{T}_{1}$ (control) with $(77.70$ cm).Singh et al., (2018), Guvvali et al., (2017) and Yadav et al., (2017)who reported that application of Copper sulphate and Zinc sulphate shows the maximum vegetative growth of the plant viz. crown height.

In terms of plant girth the maximum plant girth was recorded in in $\mathrm{T}_{11}\left(\mathrm{CuSO}_{4} @ 0.4 \%\right.$ $\left.+\mathrm{ZnSO}_{4} @ 0.4 \%\right)$ with $(17.90 \mathrm{~cm})$ followed by $\mathrm{T}_{10}\left(\mathrm{CuSO}_{4} @ 0.2 \%+\mathrm{ZnSO}_{4} @ 0.2 \%\right)$ with $(17.60 \mathrm{~cm})$ and the minimum was recorded in $\mathrm{T}_{1}$ (control) with $(16.13 \mathrm{~cm})$. This study substantiates with the studies of (Singh et al., (2018), Guvvali et al., (2017) and Yadav et al., (2017) who reported that application of Copper sulphate and zinc sulphate shows the maximum vegetative growth of the plant viz. plant girth.

In terms of number of flowers the maximum numbers of flower per plant was recorded in $\mathrm{T}_{15}\left(\mathrm{CuSO}_{4} @ 0.4 \%+\mathrm{FeSO}_{4} @ 0.4 \%+\right.$ $\mathrm{ZnSO}_{4} @ 0.4 \%$ ) with (89.00) followed by $\mathrm{T}_{14}$ $\left(\mathrm{CuSO}_{4} @ 0.2 \%+\mathrm{FeSO}_{4} @ 0.2 \%+\mathrm{ZnSO}_{4} @\right.$
$0.2 \%)$ with (82.00) which was superior over $\mathrm{T}_{1}$ (control) with (54.00) number of flowers. This study affirms with the studies carried by Saha et al., (2019), kumar et al., (2017), Yadav et al., (2017) and Venu et al., (2014) who reported that application of $\mathrm{CuSO}_{4} @$ 0.4, $\mathrm{FeSO}_{4} @ 0.4 \%, \mathrm{ZnSO}_{4} @ 0.4 \%$ shows the maximum number of flowers per plant.

In terms of number of fruit the maximum numbers of fruit per plant was recorded in $\mathrm{T}_{15}$ $\left(\mathrm{CuSO}_{4} @ 0.4 \%+\mathrm{FeSO}_{4} @ 0.4 \%+\mathrm{ZnSO}_{4} @\right.$ $0.4 \%)$ with (62.00) followed by $\mathrm{T}_{14}\left(\mathrm{CuSO}_{4} @\right.$ $\left.0.2 \%+\mathrm{FeSO}_{4} @ 0.2 \%+\mathrm{ZnSO}_{4} @ 0.2 \%\right)$ with (56.00) which was superior over $\mathrm{T}_{1}$ (control) with (29.00) number of fruit. This study is supported by the findings of Saha et al., (2019), C.J. et al., (2017) and Yadav et al., (2017) who reported that application of $\mathrm{CuSO}_{4}, \mathrm{FeSO}_{4}, \mathrm{ZnSO}_{4}$ shows the maximum number of fruits per plant.

In terms of fruit set percentage the maximum fruit set percentage was recorded in $\mathrm{T}_{15}$ $\left(\mathrm{CuSO}_{4} @ 0.4 \%+\mathrm{FeSO}_{4} @ 0.4 \%+\mathrm{ZnSO}_{4} @\right.$ $0.4 \%)$ with (69.97) followed by $\mathrm{T}_{14}\left(\mathrm{CuSO}_{4} @\right.$ $0.2 \%+\mathrm{FeSO}_{4} @ 0.2 \%+\mathrm{ZnSO}_{4} @ 0.2 \%$ ) with (68.32) which was superior over $\mathrm{T}_{1}$ (control) with (53.17). This study corroborates with the studies of Saha et al., (2019), C.J. et al., (2017) and yadav et al., (2017) who reported that application of $\mathrm{CuSO}_{4}, \mathrm{FeSO}_{4}, \mathrm{ZnSO}_{4}$ shows the maximum number of fruit set per plant.

In terms of fruit, weight the maximum fruit weight $(\mathrm{g})$ was recorded in $\mathrm{T}_{15}\left(\mathrm{CuSO}_{4} @\right.$ $\left.0.4 \%+\mathrm{FeSO}_{4} @ 0.4 \%+\mathrm{ZnSO}_{4} @ 0.4 \%\right)$ with $(180.33 \mathrm{~g})$ followed by $\mathrm{T}_{14}\left(\mathrm{CuSO}_{4} @\right.$ $\left.0.2 \%+\mathrm{FeSO}_{4} @ 0.2 \%+\mathrm{ZnSO}_{4} @ 0.2 \%\right)$ with (179.06 g) which was superior over $\mathrm{T}_{1}$ (control) with $(140.40 \mathrm{~g})$. This study is supported by the findings of Saha et al., (2019)and C.J. et al., (2017)who reported that application of $\mathrm{CuSO}_{4}, \mathrm{FeSO}_{4}, \mathrm{ZnSO}_{4}$ shows the maximum average fruit weight of fruit. 
Table.1 Effect of different treatments on various parameters of Guava

\begin{tabular}{|c|c|c|c|c|c|c|c|c|c|c|c|c|}
\hline $\begin{array}{l}\text { Notati } \\
\text { on }\end{array}$ & Treatment combination & $\begin{array}{c}\text { Plant } \\
\text { height } \\
(\mathbf{c m})\end{array}$ & $\begin{array}{c}\text { Crown } \\
\text { height } \\
\text { (cm) }\end{array}$ & $\begin{array}{l}\text { Plant } \\
\text { Girth } \\
(\mathrm{cm})\end{array}$ & $\begin{array}{c}\text { No. of } \\
\text { flowers } \\
\text { per } \\
\text { plants }\end{array}$ & $\begin{array}{c}\text { Fruit set } \\
\text { percenta } \\
\text { ge }\end{array}$ & $\begin{array}{c}\text { No. of } \\
\text { fruit } \\
\text { per } \\
\text { plant }\end{array}$ & $\begin{array}{c}\text { Average } \\
\text { fruit } \\
\text { weight (g) }\end{array}$ & $\begin{array}{c}\text { Fruit } \\
\text { yield/plant } \\
\text { (g) }\end{array}$ & $\begin{array}{l}\text { Length } \\
\text { of fruit } \\
\text { (cm) }\end{array}$ & $\begin{array}{l}\text { Width } \\
\text { of fruit } \\
\text { (cm) }\end{array}$ & $\begin{array}{c}\text { Pulp } \\
\text { thickne } \\
\text { ss (mm) }\end{array}$ \\
\hline $\mathbf{T}_{1}$ & Control & 130.96 & 77.70 & 16.13 & 54.00 & 53.17 & 29.00 & 140.40 & $4,071.80$ & 5.76 & 5.96 & 13.70 \\
\hline $\mathbf{T}_{2}$ & Copper sulphate @ $0.2 \%$ & 155.33 & 102.80 & 16.53 & 61.00 & 55.83 & 36.00 & 154.33 & $5,547.50$ & 6.26 & 6.36 & 14.23 \\
\hline $\mathbf{T}_{3}$ & Copper sulphate @ $0.4 \%$ & 156.70 & 101.63 & 16.66 & 64.00 & 63.46 & 41.00 & 157.67 & $6,457.50$ & 6.43 & 6.56 & 15.26 \\
\hline $\mathbf{T}_{4}$ & Ferrous sulphate @ $0.2 \%$ & 154.03 & 96.86 & 16.33 & 62.00 & 63.80 & 37.00 & 147.40 & $5,458.20$ & 6.13 & 6.03 & 14.20 \\
\hline $\mathbf{T}_{5}$ & Ferrous sulphate @ $0.4 \%$ & 136.20 & 80.56 & 16.73 & 63.00 & 64.18 & 38.00 & 150.50 & $5,719.00$ & 6.36 & 6.26 & 15.16 \\
\hline$T_{6}$ & Zinc Sulphate @ $0.2 \%$ & 146.96 & 87.40 & 17.03 & 70.00 & 63.03 & 43.00 & 164.33 & $7,066.50$ & 6.66 & 6.63 & 16.66 \\
\hline $\mathbf{T}_{7}$ & Zinc Sulphate@0.4\% & 150.73 & 98.23 & 17.00 & 70.00 & 64.63 & 44.00 & 166.16 & $7,309.70$ & 6.76 & 6.76 & 16.86 \\
\hline $\mathbf{T}_{8}$ & $\begin{array}{c}\mathrm{CuSO}_{4} @ 0.2 \%+\mathrm{FeSO}_{4} @ \\
0.2 \%\end{array}$ & 169.86 & 106.13 & 16.86 & 64.00 & 63.06 & 39.00 & 154.40 & $6,009.90$ & 6.53 & 6.53 & 15.70 \\
\hline $\mathbf{T}_{9}$ & $\begin{array}{c}\mathrm{CuSO}_{4} @ 0.4 \%+\mathrm{FeSO}_{4} @ \\
0.4 \%\end{array}$ & 154.03 & 93.16 & 17.43 & 59.00 & 63.12 & 36.00 & 161.30 & $5,809.20$ & 6.56 & 6.43 & 16.26 \\
\hline $\mathbf{T}_{10}$ & $\begin{array}{c}\mathrm{CuSO}_{4} @ 0.2 \%+\mathrm{ZnSO}_{4} @ \\
0.2 \%\end{array}$ & 170.0 & 107.76 & 17.60 & 74.00 & 63.35 & 44.00 & 167.06 & $7,347.80$ & 6.63 & 6.50 & 16.03 \\
\hline $\mathbf{T}_{11}$ & $\begin{array}{c}\mathrm{CuSO}_{4} @ 0.4 \%+\mathrm{ZnSO}_{4} @ \\
0.4 \%\end{array}$ & 183.0 & 117.20 & 17.90 & 76.00 & 62.12 & 47.00 & 172.23 & $8,095.50$ & 6.76 & 6.66 & 16.36 \\
\hline $\mathbf{T}_{12}$ & $\begin{array}{c}\mathrm{FeSO}_{4} @ 0.2 \%+\mathrm{ZnSO}_{4} @ \\
0.2 \%\end{array}$ & 137.70 & 79.30 & 17.30 & 68.00 & 63.56 & 41.00 & 165.66 & $6,786.00$ & 6.70 & 6.60 & 16.30 \\
\hline $\mathbf{T}_{13}$ & $\begin{array}{c}\mathrm{FeSO}_{4} @ 0.4 \%+\mathrm{ZnSO}_{4} @ \\
0.4 \%\end{array}$ & 142.66 & 87.20 & 17.30 & 67.00 & 63.43 & 42.00 & 166.83 & $7,012.00$ & 6.86 & 6.83 & 16.60 \\
\hline $\mathbf{T}_{14}$ & $\begin{array}{c}\mathrm{CuSO}_{4} @ 0.2 \%+\mathrm{FeSO}_{4} @ \\
0.2 \%+\mathrm{ZnSO}_{4} @ 0.2 \%\end{array}$ & 143.03 & 88.20 & 16.86 & 82.00 & 68.32 & 56.00 & 179.06 & $10,024.40$ & 7.14 & 7.06 & 17.10 \\
\hline \multirow[t]{4}{*}{$\mathbf{T}_{15}$} & $\begin{array}{c}\mathrm{CuSO}_{4} @ 0.4 \%+\mathrm{FeSO}_{4} @ \\
0.4 \%+\mathrm{ZnSO}_{4} @ 0.4 \%\end{array}$ & 137.06 & 81.36 & 17.06 & 89.00 & 69.97 & 62.00 & 180.33 & $11,181.00$ & 7.76 & 7.42 & 17.43 \\
\hline & $\mathrm{CD}$ & 23.50 & 21.68 & 0.321 & 8.955 & 5.347 & 4.780 & 3.271 & 717.604 & 0.340 & 0.450 & 0.393 \\
\hline & SE (D) & 11.41 & 10.53 & 0.156 & 4.349 & 2.597 & 2.322 & 1.589 & 348.525 & 0.165 & 0.218 & 0.191 \\
\hline & F-Test & $\mathbf{S}$ & $\mathbf{S}$ & $\mathbf{S}$ & $\mathbf{S}$ & $\mathbf{S}$ & $\mathbf{S}$ & $\mathbf{S}$ & $\mathbf{S}$ & $\mathbf{S}$ & $\mathbf{S}$ & $\mathbf{S}$ \\
\hline
\end{tabular}


In terms of fruit yield, the maximum fruit yield per plant $(\mathrm{kg})$ was recorded in $\mathrm{T}_{15}$ $\left(\mathrm{CuSO}_{4} @ 0.4 \%+\mathrm{FeSO}_{4} @ 0.4 \%+\mathrm{ZnSO}_{4} @\right.$ $0.4 \%)$ with $(11,181.00 \mathrm{~g})$ followed by $\mathrm{T}_{14}$ $\left(\mathrm{CuSO}_{4} @ 0.2 \%+\mathrm{FeSO}_{4} @ 0.2 \%+\mathrm{ZnSO}_{4} @\right.$ $0.2 \%)$ with $(10,024.40 \mathrm{~g})$ which was superior over $\mathrm{T}_{1}$ (control) with $(4,071.80 \mathrm{~g})$. This study is in accordance with the studies of Saha et al., (2019), C.J. et al., (2017) and Yadav et al., (2017) who reported that application of $\mathrm{CuSO}_{4}, \mathrm{FeSO}_{4}, \mathrm{ZnSO}_{4}$ shows the maximum fruit yield per plant.

In terms of fruit length, the maximum fruit length was recorded in in $\mathrm{T}_{15}\left(\mathrm{CuSO}_{4} @ 0.4 \%\right.$ $\left.+\mathrm{FeSO}_{4} @ 0.4 \%+\mathrm{ZnSO}_{4} @ 0.4 \%\right)$ with $(7.76 \mathrm{~cm})$ followed by $\mathrm{T}_{15}\left(\mathrm{CuSO}_{4} @ 0.2 \%+\right.$ $\left.\mathrm{FeSO}_{4} @ 0.2 \%+\mathrm{ZnSO}_{4} @ 0.2 \%\right)$ with (7.14 $\mathrm{cm})$ which was superior over $\mathrm{T}_{1}$ (control) with $(5.76 \mathrm{~cm})$. This study substantiates with the studies of Saha et al., (2019) and C.J. et al., (2017)who reported that application of $\mathrm{CuSO}_{4}, \mathrm{FeSO}_{4}, \mathrm{ZnSO}_{4}$ shows the maximum length of fruit.

In terms of fruit width, the maximum width of fruit was recorded in in $\mathrm{T}_{15}\left(\mathrm{CuSO}_{4} @ 0.4 \%+\right.$ $\left.\mathrm{FeSO}_{4} @ 0.4 \%+\mathrm{ZnSO}_{4} @ 0.4 \%\right)$ with (7.42 $\mathrm{cm})$ followed by $\mathrm{T}_{14}\left(\mathrm{CuSO}_{4} @ 0.2 \%+\mathrm{FeSO}_{4}\right.$ @0.2\%+ $\left.\mathrm{ZnSO}_{4} @ 0.2 \%\right)$ with (7.06 cm) which was superior over $\mathrm{T}_{1}$ (control) with $(5.96 \mathrm{~cm})$. This study is supported by the findings of Saha et al., (2019) and C.J. et al., (2017)who reported that application of $\mathrm{CuSO}_{4}, \mathrm{FeSO}_{4}, \mathrm{ZnSO}_{4}$ shows the maximum width of fruit.

In terms of pulp thickness, the maximum pulp thickness was recorded in $\mathrm{T}_{15}\left(\mathrm{CuSO}_{4} @ 0.4 \%\right.$ $\left.+\mathrm{FeSO}_{4} @ 0.4 \%+\mathrm{ZnSO}_{4} @ 0.4 \%\right)$ with (17.43 mm) followed by $\mathrm{T}_{14}\left(\mathrm{CuSO}_{4} @ 0.2 \%\right.$ $+\mathrm{FeSO}_{4} @ 0.2 \%+\mathrm{ZnSO}_{4} @ 0.2 \%$ ) with $(17.10 \mathrm{~mm})$ which was superior over $\mathrm{T}_{1}$ (control) with $(13.70 \mathrm{~mm})$. This study is in accordance with the studies of (Tirkey et al., (2018), Sau et al., (2018)and Suman and
Tambe. (2015) who reported that application of $\mathrm{CuSO}_{4}, \mathrm{FeSO}_{4}, \mathrm{ZnSO}_{4}$ shows the maximum pulp thickness of guava fruit.

On the basis of results obtained, It is concluded that the treatment $\mathrm{T}_{11}\left(\mathrm{CuSO}_{4} @\right.$ $0.4 \%+\mathrm{ZnSO}_{4} @ 0.4 \%$ ) found to be best in terms of plant height, plant crown, plant girth. On the basis of results obtained, It is concluded that the treatment $\mathrm{T}_{15}\left(\mathrm{CuSO}_{4} @\right.$ $0.4 \%+\mathrm{FeSO}_{4} @ 0.4 \%+\mathrm{ZnSO}_{4} @ 0.4 \%$ ) first flower opening, number of flower per plant, number of fruit per plant, fruit set percentage, fruit weight and yield per plant. Application foliar spray of micronutrients $\left(\mathrm{CuSO}_{4}, \mathrm{FeSO}_{4}\right.$, $\mathrm{ZnSO}_{4}$ ) become powerful tools to modify several physiological processes in plants which are extensively and profitably used in horticultural crops. They are also used for increasing plant growth and increase fruit yield per hectare.

\section{References}

Agnihotri, R.P. and Bhullar, J.S. (2002). Chemical deblossoming of guava cv. Allahabad Safeda'. Hr. J. Hort. Sci. 8: 203-204.

Ashutosh Kumar Singh, VM Prasad, Devi Singh, Vijay Bahadur, T Thomas and Anil Kumar (2018) Effect of different combinations of PGR's and micronutrients on growth and flowering of papaya (Carica papaya L.) cv. pusa Nanha Journal of Pharmacognosy and Phytochemistry 2018; 7(6): 1326-1329.

Horticultural Statistics at a Glance (2018).Horticulture statistics division, Department of Agriculture, Coopn \& Farmers Welfare, 2018.

Kumar J, Kumar R, Rai R, Mishra D.(2015) Response of Pant Prabhat guava trees to foliar sprays of zinc, boron, calcium and potassium at different plant growth stages. The Bioscan, 2015; 10(2):495-498.

Mahaveer Suman, S.V. Dubalgunde, Ooty Poobalan and Pency D. Sangam. (2016) 
Efficacy of Foliar Application of Micronutrients on Yield and Economics of guava cv. L-49Int. Journal of Agri, Environment and biotechnology, 9(2): 221-224.

Mahaveer Suman, Tambe T.B. (2015) Effect of foliar application of micronutrients on growth, yield and quality of guava (Psidium guajava L.) Cv. L-49, M.Sc (Hort.). Thesis Submitted to Vasantrao Naik Marathwada Krishi Vidyapeeth, Parbhani.

Mitra, S.K. and Bose T.K. (2001). Fruis: Tropical \& Sub tropical VI. Naya udyog, Calcutta, pp 610-611.

Nithin Kumar C. J., Rajangam J., Balakrishnan K. and Sampath P. M. (2017) Influence of Foliar Application of Micronutrients on Yield and Quality of Mandarin Orange (Citrus reticulata Blanco.) Under Lower Pulney Hills. International Journal of Agriculture Sciences ISSN: 0975-3710\&EISSN: 0975-9107, Volume 9, Issue 17, 2017.

NR Tirkey, RN Kanpure, BK Kachouli, J Bhandari and DK Patidar. (2018) Effect of foliar nutrition of Zinc sulphate, borax and NAA on yield and quality of Guava (Psidium guajava L.) $c v$. Allahabad Safeda International Journal of Chemical Studies 2018; 6(4): 2295-2298.

Pankaj Kumar, A.K. Singh and Shankhdhar, S.C. (2017) Efficacy of Soil and Foliar Application of Macro and Micronutrients on Yield and Quality of Mango cv. Dashehari. Int. J. Curr. Microbiol. App. Sci. 6(10): 1855-1861.

Sayan Sau, Sukamal Sarkar, Bikash Ghosh, Krishnedu Ray, Prahlad Deb and Dibakar Ghosh. (2018) Effect of Foliar Application of $\mathrm{B}, \mathrm{Zn}$ and $\mathrm{Cu}$ on Yield, Quality and Economics of Rainy Season Guava Cultivation, British Journal of Applied Science \& Technology, ISSN: 2231-0843, NLM ID: 101664541.

Shukla AK, Kaushik RA, Pandey D, Sarolia DK. (2008) In: Guava. Published by Maharana Pratap University of Agriculture and Technology, Udaipur, 2008, 7.

T. Saha, B. Ghose, S. Debnath and A. Bhattacharjee (2019) Effect of micronutrients on growth, yield and quality of strawberry (Fragaria $\times$ ananassa Duch.) cv. Winter Dawn in the Gangetic Alluvial Region of West Bengal, Journal of Crop and Weed, 15(1): 92-95 (2019).

Thirupathaiah Guvvali, Sampath. P. M, Bhaskar RaoB, Nirmala. $\mathrm{P}$ and Sumangala Koulagi. (2017) Influence of Micronutrients on Growth, Yield and Economy of Sapota Cv. Kalipatti under HDP System, International Journal of Agricultural Science and Research (IJASR). Vol. 7, Issue 3, Jun 2017, 401408.

Venu, A., Delvadia, D. V., Sharma, L. K., and Makhmale, S. (2014) Effect of micronutrients application on flowering, fruiting and yield of acid lime cv. Kagzi lime. Int. J. Tropi. Agric. Serials Publications, 32(3-4): 331-334.

Yadav, P., Sharma, J.R., Rupakshi, Baloda, S. and Kant, G. (2017) Influence of foliar application of nutrients on growth, flowering, fruiting and yield of guava (Psidium guajava) cv. L-49, Int. J. Pure App. Biosci. 5(5): 1217-1222 (2017).

\section{How to cite this article:}

Saurabh Mani Maurya and Deena Wilson. 2020. A Study on Effect of Foliar Application of Micronutrients on Growth, Fruit Set and Yield of Guava Cv. Allahabad Safeda. Int.J.Curr.Microbiol.App.Sci. 9 (11): 1234-1240. doi: https://doi.org/10.20546/ijcmas.2020.911.145 